\title{
Co-expression of gastric and biliary phenotype in pyloric-gland type adenoma of the gallbladder: Immunohistochemical analysis of mucin profile and CD10
}

\author{
SHIGENORI NAGATA ${ }^{1}$, YOICHI AJIOKA ${ }^{2}$, KEN NISHIKURA $^{2}$, GEN WATANABE ${ }^{2}$, TAKAHIRO INOUE ${ }^{1}$, \\ KOJI YAMAGUCHI ${ }^{3}$, HIDENOBU WATANABE $^{4}$, MASAO TANAKA ${ }^{3}$ and MASAZUMI TSUNEYOSHI ${ }^{1}$ \\ ${ }^{1}$ Department of Anatomic Pathology, Kyushu University Faculty of Medicine, Fukuoka; ${ }^{2}$ Division of Molecular and \\ Diagnostic Pathology, Department of Molecular Genetics, Niigata University Graduate School of Medical and \\ Dental Science; ${ }^{3}$ Department of Surgery and Oncology, Kyushu University Faculty of Medicine, Fukuoka; \\ ${ }^{4}$ Niigata University Graduate School of Medical and Dental Science, Niigata, Japan
}

Received October 2, 2006; Accepted November 28, 2006

\begin{abstract}
Pyloric-gland type adenoma of the gallbladder is formed by proliferation of glands resembling pyloric glands, morphologically. No previous report has described the cellular phenotype and differentiation of pyloric-gland type adenoma of the gallbladder, using CD10 as a marker of proper biliary phenotype. Immunostainings were performed for mucin markers such as MUC5AC, human gastric mucin (HGM) for gastric foveolar type epithelium, MUC6, M-GGMC-1 for pyloric-gland type and MUC2 for intestinal goblet-cell type, and for CD10 as a proper biliary type marker on 58 pyloricgland type adenomas of the gallbladder, as well as for p53, Ki-67 and CDX2. The percentage (X) of reactive cells in relation to the total number of tumor cells was estimated semi-quantitatively, and divided into four categories: $\mathrm{X}=0 \%$ (negative), $0 \%<X<10 \%, 10 \% \leq X<30 \%$, and $X \geq 30 \%$. CDX2 expression was considered to be positive when the percentage of positively stained cells was $\geq 10 \%$. Out of the 58 pyloricgland type adenomas, $\geq 30 \%$ of adenoma cells were positive for MUC5AC in 22 (38\%) tumors, HGM in 29 (50\%), MUC6 in $58(100 \%)$, M-GGMC-1 in $54(93 \%)$, MUC2 in none $(0 \%)$, and CD10 in $20(34 \%)$. MUC6 $(\mathrm{P}<0.001)$ and M-GGMC-1 $(\mathrm{P}<0.001)$ mucins were detected more frequently in pyloricgland type adenomas, and CD10 expression was significantly decreased, compared with normal gallbladder epithelium $(\mathrm{P}=0.006)$. $\mathrm{P} 53$ overexpression was not found in any of the 58 tumors, including two adenomas with carcinomatous foci.
\end{abstract}

Correspondence to: Dr Shigenori Nagata, Department of Anatomic Pathology, Graduate School of Medical Sciences, Kyushu University, 3-1-1 Maidashi, Higashi-ku, Fukuoka 812-8582, Japan

E-mail: shnagata@surgpath.med.kyushu-u.ac.jp

Key words: adenoma, CD10, CDX2, gallbladder, mucins, phenotype, pyloric glands
The mean number of Ki-67-positive cells was $10.3 \pm 5.8 \%$. CDX2 expression was judged as negative in all 58 pyloricgland type adenomas. In pyloric-gland type adenomas of the gallbladder, expression of pyloric-gland type mucins was observed with a high frequency, whereas intestinal goblet-cell mucins were rarely seen. In addition, co-expression of gastric foveolar type mucins and CD10 was also demonstrated. Pyloric-gland type adenomas of the gallbladder show a differentiation toward pyloric glands in terms of immunohistochemistry, as well as morphology, accompanied by co-expression of gastric foveolar and native biliary phenotypes.

\section{Introduction}

Although adenoma of the gallbladder is a rare benign tumor, it has been established as an important precursor lesion that plays a part in gallbladder carcinogenesis $(1,2)$. According to its growth and structural pattern, it is divided into three subtypes: tubular, papillary and tubulopapillary, and it is also classified histogenetically as pyloric gland, intestinal and biliary types $(1,2)$. Among these, the most common form is tubular adenoma of pyloric gland type $(1,3)$, which is typically present as well-demarcated, polypoid lesions in the gallbladder. Histologically, these tumors are composed of lobules with closely packed glands that resemble pyloric glands, some of which are cystically dilated $(1,2)$. Pyloric-gland type adenoma of the gallbladder usually displays a range of epithelial dysplastic changes, often co-existing with hyperplastic and metaplastic lesions, giving rise to considerable confusion in diagnosis $(1,3)$.

Mucins are a group of high-molecular-weight glycoproteins consisting of a mucin core protein (apomucin) and many O-linked carbohydrate side chains (4-6). Previous progress in immunohistochemistry has suggested a unique role for mucin markers based on their tissue- and cell-specific expression and distribution patterns in individual organs (7). To date, a series of human mucin genes have been assigned to the MUC gene family that are approved by the Human Genome Organization Gene Nomenclature Committee (HUGO/GNC; 
Table I. Immunohistochemical markers used for determining the phenotype of gallbladder epithelium.

\begin{tabular}{|c|c|c|c|c|c|c|}
\hline & \multicolumn{2}{|c|}{ Gastric foveolar type } & \multicolumn{2}{|c|}{ Pyloric-gland type } & \multirow{2}{*}{$\begin{array}{c}\text { Intestinal goblet-cell type } \\
\text { MUC2 }\end{array}$} & \multirow{2}{*}{$\begin{array}{l}\text { Proper biliary type } \\
\text { CD10 }\end{array}$} \\
\hline & MUC5AC & HGM & MUC6 & M-GGMC-1 & & \\
\hline Antibody clone & CLH2 & $45 \mathrm{M} 1$ & CLH5 & HIK1083 & Ccp58 & $56 \mathrm{C} 6$ \\
\hline Specificity & $\begin{array}{l}\text { Human Muc-5AC } \\
\text { glycoprotein }\end{array}$ & $\begin{array}{l}\text { Peptide core of human } \\
\text { gastric mucin }\end{array}$ & $\begin{array}{l}\text { Human Muc-6 } \\
\text { glycoprotein }\end{array}$ & $\begin{array}{l}\alpha \text {-linked GlcNAc } \\
\text { residue }\end{array}$ & $\begin{array}{l}\text { Human Muc-2 } \\
\text { glycoprotein }\end{array}$ & CD10 glycoprotein \\
\hline $\begin{array}{l}\text { Positive cells in } \\
\text { non-neoplastic } \\
\text { gallbladder } \\
\text { epithelium }\end{array}$ & $\begin{array}{l}\text { Mucous epithelium } \\
\text { predominantly at the } \\
\text { superficial site of } \\
\text { crypt-like structure } \\
\text { in normal mucosa }\end{array}$ & $\begin{array}{l}\text { Mucous epithelium } \\
\text { predominantly at the } \\
\text { superficial site of } \\
\text { crypt-like structure } \\
\text { in normal mucosa }\end{array}$ & $\begin{array}{l}\text { Mucous epithelium } \\
\text { predominantly at the } \\
\text { bottom site of } \\
\text { crypt-like structure } \\
\text { in normal mucosa, } \\
\text { metaplastic pyloric } \\
\text { type epithelium }\end{array}$ & $\begin{array}{l}\text { Metaplastic pyloric } \\
\text { type epithelium } \\
\text { with grandular } \\
\text { structure, } \\
\text { including } \\
\text { neck glands }\end{array}$ & $\begin{array}{l}\text { Metaplastic } \\
\text { epithelium of } \\
\text { goblet-cell type }\end{array}$ & $\begin{array}{l}\text { Proper biliary } \\
\text { epithelium }\end{array}$ \\
\hline Staining pattern & Intracytoplasmic & $\begin{array}{l}\text { Intracytoplasmic } \\
\text { and luminal } \\
\text { membranous }\end{array}$ & Intracytoplasmic & $\begin{array}{l}\text { Intracytoplasmic } \\
\text { and luminal } \\
\text { membranous }\end{array}$ & Intracytoplasmic & $\begin{array}{l}\text { Apical at the striated } \\
\text { border and rarely } \\
\text { intracytoplasmic }\end{array}$ \\
\hline Working dilution & $1: 100$ & $1: 50$ & $1: 100$ & $1: 50$ & $1: 500$ & $1: 200$ \\
\hline Source & $\begin{array}{l}\text { Novocastra, } \\
\text { Newcastle, UK }\end{array}$ & $\begin{array}{l}\text { Novocastra, } \\
\text { Newcastle, UK }\end{array}$ & $\begin{array}{l}\text { Novocastra, } \\
\text { Newcastle, UK }\end{array}$ & $\begin{array}{l}\text { Kanto Chemical, } \\
\text { Tokyo, Japan }\end{array}$ & $\begin{array}{l}\text { Novocastra, } \\
\text { Newcastle, UK }\end{array}$ & $\begin{array}{l}\text { Novocastra, } \\
\text { Newcastle, UK }\end{array}$ \\
\hline
\end{tabular}

http://www.gene.ucl.ac.uk/nomenclature/) (8). Because the genes belonging to the MUC series express their associated proteins, they have been accepted as valid immunohistochemical markers for determining cellular phenotypes in both neoplastic and non-neoplastic lesions in various organs. Among these, MUC2, MUC5AC and MUC6 genes are clustered within the $11 \mathrm{p} 15$ locus (9), classified as secretory-type mucins, and specifically express the mucins associated with intestinal goblet cell, gastric foveolar and pyloric-gland type adenomas, respectively (10-15).

In pyloric-gland type adenoma of the gallbladder, some authors have analyzed their mucin profile by using immunohistochemical markers of the MUC series $(8,16)$. In the present study, we describe the systematic analysis of the mucin profile of pyloric-gland type adenoma of the gallbladder, using a series of mucin markers; MUC5AC, human gastric mucin (HGM), MUC6, M-GGMC-1 and MUC2, and CD10 as a proper biliary type marker. In addition, we also investigated the potential for intestinal differentiation of the adenomas by immunohistochemical staining for CDX2, a caudal-related homeobox gene that plays an important role in the regulation of cell proliferation and differentiation in the gut, or intestinal metaplasia in other organs (17-19), in an attempt to better understand the cytological nature of this tumor.

\section{Materials and methods}

Materials. Out of the 13,223 gallbladders, all of which were examined at the Division of Molecular and Diagnostic Pathology, Graduate School of Medical and Dental Science, Niigata University, Japan, between 1981 and 2003, 81 (0.6\%) gallbladder adenomas (78 of pyloric gland type, three of intestinal type, and none of biliary type) were obtained for the present study. Because intestinal type adenomas were extremely rare and small in number, only 78 pyloric-gland type adenomas from 59 patients were assessed clinicopathologically.
After all the resected specimens were routinely fixed in $10 \%$ buffered formalin, the size and gross type of tumors were determined by macroscopic examination. Consecutive, $4 \mathrm{~mm}$ wide sections were cut and embedded in paraffin-blocks. Serial $3 \mu$ m-thick hematoxylin and eosin (H\&E)-stained sections were cut and examined microscopically.

Immunohistochemistry. Out of 78 pyloric-gland type adenomas of the gallbladder, paraffin-embedded tissue samples were available for immunohistochemical staining from 58 adenomas. Nine serial sections were obtained from the representative paraffin block of each tissue sample. After deparaffinization, the tissue sections were heated by 20-min microwave treatment, and allowed to cool to room temperature. Nonspecific binding was blocked with normal serum (Nichirei, Tokyo, Japan). The tissue sections with the primary antibodies were incubated overnight at $4^{\circ} \mathrm{C}$, and then with biotinylated secondary antibodies (Nichirei) for $30 \mathrm{~min}$ at room temperature, followed by treatment with the streptavidin-biotinylated peroxidase complex reagent (Nichirei). Immunohistochemical staining was performed following the manufacturer's instructions. Six specific immunohistochemical markers used in this study are listed in Table I. Immunohistochemical staining for the same series of markers as above was also performed on another six gallbladders without neoplasms or severe inflammation, to compare the immunohistochemistry of 58 pyloric-gland type adenomas with normal gallbladder epithelium. To evaluate the presence of mutated inhibitory oncogene and the proliferative activity of tumor cells, immunostaining for p53 and Ki-67 was performed by the streptoavidin-biotin method using monoclonal antibody PAb1801 (p53) and monoclonal antibody MIB-1 (Ki-67), respectively. In addition, to investigate the potential for intestinal differentiation of tumor cells, CDX2 immunostaining was performed using monoclonal antibody to CDX2 protein. The antibodies to p53, Ki-67 and CDX2 used in this study and the immunohistochemical methods are summarized 
Table II. Summary of antibodies to p53, Ki-67 and CDX2 and immunohistochemical methods.

\begin{tabular}{|c|c|c|c|c|c|}
\hline Antigen & Clone & Specificity & Dilution & Antigen retrieval & Source \\
\hline p53 & PAb1801 & p53 protein & 1:400 & Microwave & Oncogene Science, Cambridge, MA, USA \\
\hline $\mathrm{Ki}-67$ & MIB-1 & Ki-67 protein & $1: 100$ & Autoclave & Immunotech, Marseille, France \\
\hline CDX2 & CDX2-88 & $\mathrm{CDX} 2$ protein & $1: 200$ & Microwave & BioGenex, San Ramon, CA, USA \\
\hline
\end{tabular}

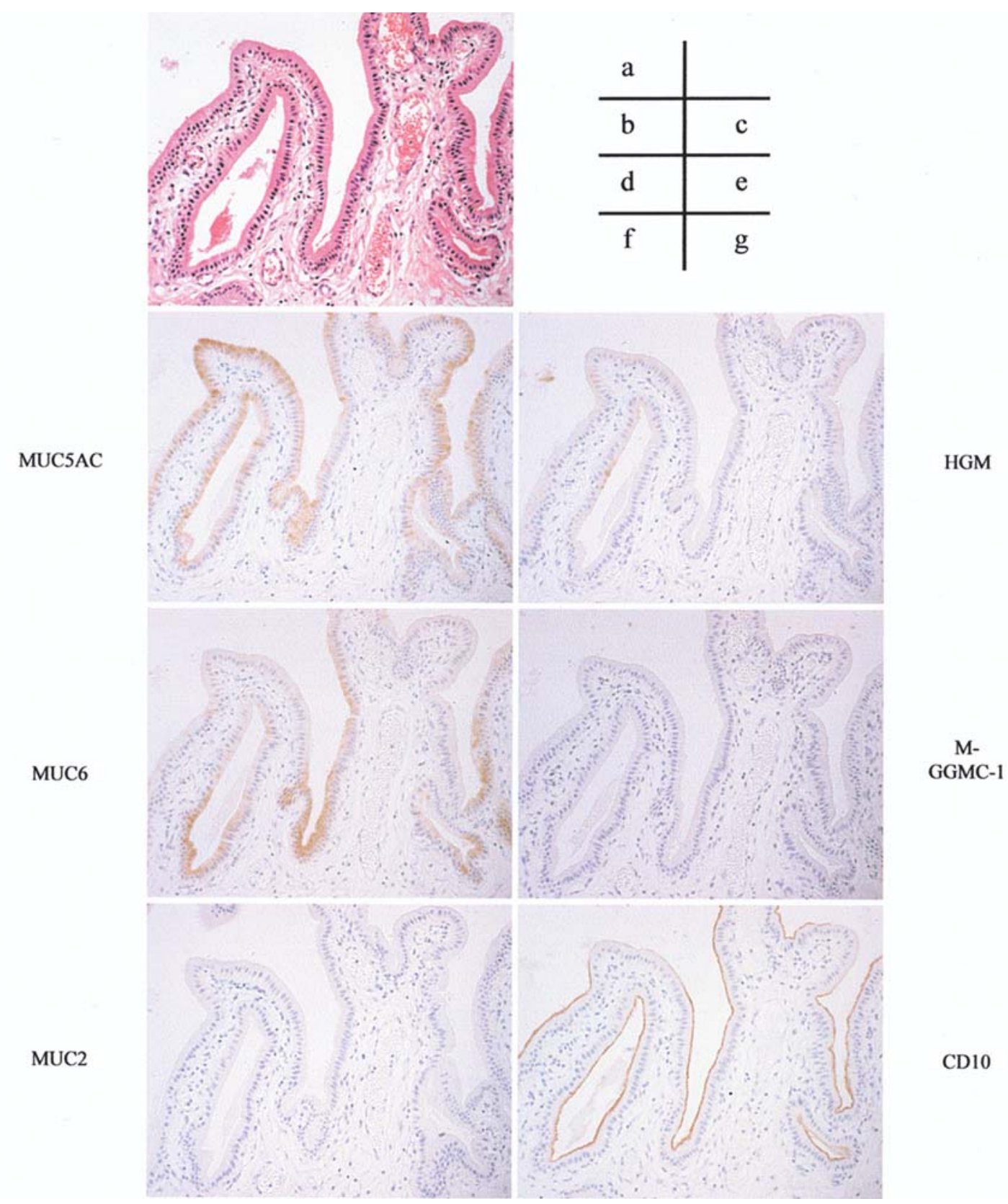

Figure 1. Immunohistochemical staining of proper gallbladder epithelium: (a) H\&E section, (b) MUC5AC, (c) HGM, (d) MUC6, (e) M-GGMC-1, (f) MUC2 and (g) CD10 (x200).

in Table II. Light counterstaining was performed with Mayer's hematoxylin in all the immunostaining experiments.

Analysis of immunostaining for MUC5AC, HGM, MUC6, M$G G M C-1, M U C 2$ and $C D 10$. The five specific mucin markers and $\mathrm{CD} 10$ were used to determine the phenotypes of 58 pyloric-gland type adenomas: MUC5AC and HGM for gastric foveolar type, MUC6 and M-GGMC-1 for pyloric-gland type, MUC2 for intestinal goblet-cell type, and CD10 for proper biliary type. The reactive sites of individual cells in nonneoplastic gallbladders are also demonstrated in Table I (Fig. 1). We considered expression in the cytoplasm as 
Table III. Clinicopathological features of 78 pyloric-gland type adenomas of the gallbladder.
Patients/no. of tumors

$59 / 78^{\mathrm{a}}$

Age, years

$\operatorname{Sex}(M / F)$

Prevalence of complicating

cholelithiasis

Location $(\mathrm{Gf} / \mathrm{Gb} / \mathrm{Gn})^{\mathrm{c}}$

Size, $\mathrm{mm}$

$63.8 \pm 2.7(39-86)^{\mathrm{b}}$

$18 / 41$

$69 \%(33 / 48)$

$15 / 37 / 23^{\mathrm{d}}$

$1.0-40.0$

(mean, 9.8; median, 6.0)
aSix women and three men had a double lesion of adenoma, and five women had a triple lesion. ${ }^{b}$ Values are means $\pm \mathrm{SD}$ followed by the range in parentheses. ' $\mathrm{Gf}$, gallbladder fundus; $\mathrm{Gb}$, gallbladder body; and $\mathrm{Gn}$, gallbladder neck. ${ }^{\mathrm{d}}$ The locations of three adenomas were not identified because of detachment from the wall.

positive reactivity for MUC5AC, MUC6 and MUC2, while expression both in the cytoplasm and on the luminal membrane was positive for HGM and M-GGMC-1. CD10 was regarded as a marker for proper biliary epithelium, when it was expressed at the striated border on the luminal surface of the epithelium. Extracellular luminal mucin reactive for each staining was excluded from this study. When the internal positive or negative controls were not stained as expected, repeated immunostaining was performed for the same tissue blocks. The percentage (X) of reactive cells in relation to the total number of tumor cells was estimated semi-quantitatively, and divided into four categories: $\mathrm{X}=0 \%$ (negative), $0 \%<\mathrm{X}<10 \%, 10 \% \leq \mathrm{X}<30 \%$, and $X \geq 30 \%$.

Analysis of KI-67, p53 and CDX2 immunostaining. P53- and $\mathrm{Ki}-67$-positive cells were defined as reactive cells with staining in the nucleus, regardless of the staining intensity. Cells with intranuclear biotin inclusion were not included among the positive cells. The positive index both for p53 and Ki-67 indicated the ratio of positive cells in relation to the total tumor cells that were counted (at least 500), especially in areas where positive cells were most diffusely distributed. P53 protein overexpression was defined as a focally aggregated or diffuse expression pattern, in contrast to negative or sporadic expression. In the present study, we used CDX2 as an indicator for potential intestinal cell differentiation. Brown staining in the nucleus only was defined as being positive for CDX2 expression, and immnostaining was judged positive when CDX2 was expressed in $\geq 10 \%$ of tumor cells. When $<10 \%$ of tumor cells were stained, the result was considered to be negative. Moreover, we also performed immunohistochemical staining for CDX2 in 10 normal gallbladders, and in our series of three intestinal type adenomas of the gallbladder, as negative and positive controls, respectively, to compare the positivity with that of the 58 pyloric-gland type adenomas.

Statistical analysis. Statistical analysis was performed using Mann-Whitney's U test or Fisher's exact test to compare the mucin expression profile between normal proper gallbladder
Table IV . Relationship between gross type and tumor size in 78 pyloric-gland type adenomas of the gallbladder.

\begin{tabular}{lcccc}
\hline & \multicolumn{3}{c}{ Tumor size (X), mm } & \begin{tabular}{c} 
No. of \\
tumors \\
\cline { 2 - 4 } Gross type
\end{tabular} \\
\cline { 2 - 5 } & $\begin{array}{c}\mathrm{X}<10 \\
\mathrm{n}(\%)\end{array}$ & $\begin{array}{c}10 \leq \mathrm{X}<30 \\
\mathrm{n}(\%)\end{array}$ & $\begin{array}{c}\mathrm{X} \geq 30 \\
\mathrm{n}(\%)\end{array}$ & $\mathrm{n}(\%)$ \\
\hline Pedunculated type & 33 & 20 & $4^{\mathrm{a}}$ & $57(73 \%)$ \\
Sessile type & 20 & 1 & 0 & $21(27 \%)$ \\
No. of tumors [n (\%)] & $53(68 \%)$ & $21(27 \%)$ & $4^{\mathrm{a}}(5 \%)$ & $78(100 \%)$ \\
\hline
\end{tabular}

aTwo of four adenomas had carcinomatous foci.

Table V. Relative frequencies in accordance with the degree of distribution of positive cells for mucin markers and CD10 in 58 pyloric-gland type adenomas of the gallbladder.

\begin{tabular}{lccccc}
\hline \multicolumn{5}{c}{$\begin{array}{c}\text { Percentage of reactive cells within } \\
\text { total tumor cells }(\mathrm{X})\end{array}$} \\
$\begin{array}{l}\text { Immuno- } \\
\text { histochemical } \\
\text { markers }\end{array}$ & $\begin{array}{c}\mathrm{X}=0 \% \\
\mathrm{n}(\%)^{\mathrm{a}}\end{array}$ & $\begin{array}{c}0 \%<\mathrm{X}<10 \% \\
\mathrm{n}(\%)^{\mathrm{a}}\end{array}$ & $\begin{array}{c}10 \% \leq \mathrm{X}<30 \% \\
\mathrm{n}(\%)^{\mathrm{a}}\end{array}$ & $\begin{array}{c}\mathrm{X} \geq 30 \% \\
\mathrm{n}(\%)^{\mathrm{a}}\end{array}$ & $\begin{array}{c}\text { Total } \\
\text { tumors }\end{array}$ \\
\hline MUC5AC & $0(0 \%)$ & $20(34 \%)$ & $16(28 \%)$ & $22(38 \%)$ & 58 \\
HGM & $0(0 \%)$ & $15(26 \%)$ & $14(24 \%)$ & $29(50 \%)$ & 58 \\
MUC6 & $0(0 \%)$ & $0(0 \%)$ & $0(0 \%)$ & $58(100 \%)$ & 58 \\
M-GGMC-1 & $0(0 \%)$ & $2(3 \%)$ & $2(3 \%)$ & $54(93 \%)$ & 58 \\
MUC2 & $16(28 \%)$ & $42(72 \%)$ & $0(0 \%)$ & $0(0 \%)$ & 58 \\
CD10 & $0(0 \%)$ & $26(45 \%)$ & $12(21 \%)$ & $20(34 \%)$ & 58 \\
\hline
\end{tabular}

aPercentages do not always total 100 because of rounding.

epithelium and pyloric-gland type adenomas of the gallbladder. $\mathrm{P}<0.05$ was considered statistically significant.

\section{Results}

Clinicopathological features of pyloric-gland type adenoma of the gallbladder. Seventy eight pyloric-gland type adenomas obtained from $59(0.4 \%)$ patients were identified in 13,223 gallbladders removed for inflammation or neoplasms in our institute over the past 23 years. The clinicopathological features of our series of 78 pyloric-gland type adenomas are shown in Table III. Forty-five (76\%) of the 59 patients had a solitary tumor, while the remaining 14 (24\%) had multiple lesions. The age of the patients ranged from 39 to 86 years, with a mean of 63.8 years. There were $41(69 \%)$ female and $18(31 \%)$ male patients. Thirty-three $(69 \%)$ of the 48 patients known to have cholelithiasis presented with complications. The most common location of the lesions was the body of the gallbladder, followed by the neck, with 37 and 23 tumors, respectively. The largest diameter of the tumors was 1.0$40.0 \mathrm{~mm}$, with a mean and median of 9.8 and $6.0 \mathrm{~mm}$, respectively. The relationship between the gross type and size of the pyloric-gland type adenomas of the gallbladder is shown in Table IV. Fifty-seven (73\%) of 78 lesions were pedunculated, while the remaining $21(27 \%)$ were sessile or 

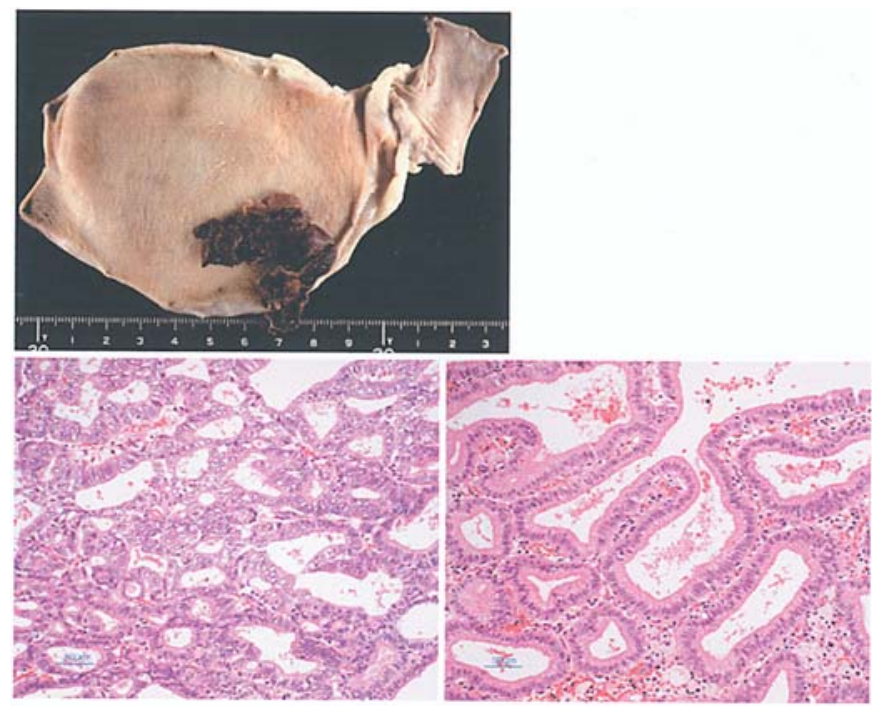

Figure 2. Adenocarcinoma arising from tubular adenoma in a 60-year-old Japanese man: (a) macroscopic findings, (b) H\&E section of foci of welldifferentiated adenocarcinoma versus (c) component of tubular adenoma of pyloric-gland type (x200) low elevated lesions. Fifty-one (65\%) of the 78 adenomas were small, with a largest diameter $<10 \mathrm{~mm}$. On the other hand, four $(5 \%)$ pedunculated lesions were $\geq 30 \mathrm{~mm}$ in diameter. Two of these four large tumors had focal carcinomatous areas, in which the tumor cells demonstrated a higher degree of atypical cytology (Fig. 2). Briefly, the histopathological criteria used to distinguish carcinoma from adenoma were nuclear size and minor axis, nuclear shape and polarity, chromatin pattern and cytoplasmic features. Areas of carcinomatous transformation arose in the adenomas, either as solitary or multiple foci, where the carcinoma cells were confined to the epithelium, without stromal invasion both in the stalk and in the surrounding mucosa.

Mucin markers and CD10 expression profile based on the immunohistochemical stainings. In relation to the degree of distribution of cells positive for the six immunohistochemical markers, the relative frequency of pyloric-gland type adenoma of the gallbladder is shown in Table V and Fig. 3. MUC5AC, HGM, MUC6, M-GGMC-1 and CD10 were expressed in all 58 pyloric-gland type adenomas of the gallbladder, however,
MUC5AC

MUC6

MUC2

Ki-67
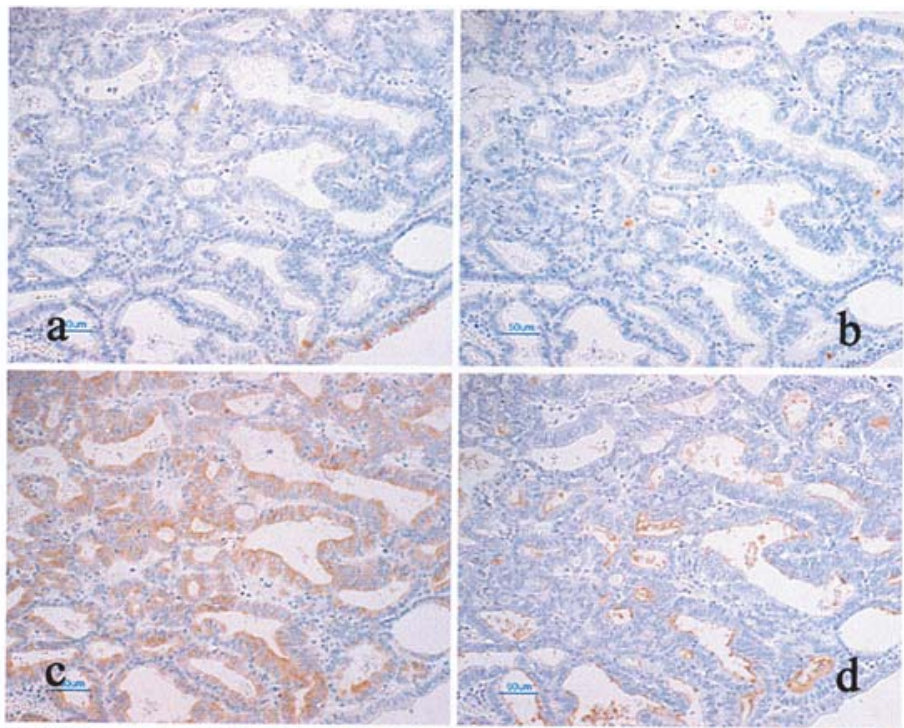

HGM

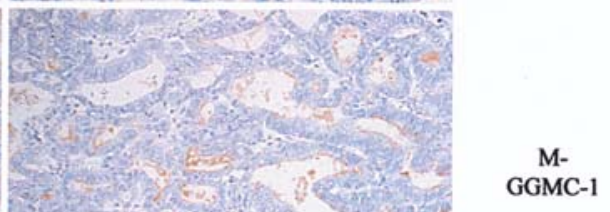

GGMC-1

CD10

p53

Figure 3. Expression of immunohistochemical markers in pyloric-gland type adenoma of the gallbladder: (a) MUC5AC, (b) HGM, (c) MUC6, (d) M-GGMC-1, (e) MUC2, (f) CD10, (g) Ki-67 and (h) p53 (x200). 
Table VI. Comparison of the immunohistochemical expression profile between pyloric-gland type adenomas of the gallbladder and normal gallbladder epithelium.

\begin{tabular}{|c|c|c|c|c|c|c|}
\hline \multirow[b]{2}{*}{$\begin{array}{l}\text { Immunohistochemical } \\
\text { markers }\end{array}$} & & \multicolumn{3}{|c|}{ Percentage of reactive cells relative to the total number of tumor cells } & \multirow[b]{2}{*}{$\mathrm{P}$} & \multirow{2}{*}{$\begin{array}{c}\text { Total } \\
\text { tumors } \\
\text { n }\end{array}$} \\
\hline & & $\begin{array}{c}0 \% \leq \mathrm{X}<10 \% \\
\mathrm{n}(\%)^{\mathrm{a}}\end{array}$ & $\begin{array}{c}10 \% \leq \mathrm{X}<30 \% \\
\mathrm{n}(\%)^{\mathrm{a}}\end{array}$ & $\begin{array}{l}\mathrm{X} \geq 30 \% \\
\mathrm{n}(\%)^{\mathrm{a}}\end{array}$ & & \\
\hline \multirow[t]{2}{*}{ MUC5AC } & NE & $0(0 \%)$ & $2(33 \%)$ & $4(67 \%)$ & & 6 \\
\hline & $\mathrm{AD}$ & $20(34 \%)$ & $16(28 \%)$ & $22(38 \%)$ & & 58 \\
\hline \multirow[t]{2}{*}{ HGM } & $\mathrm{NE}$ & $1(17 \%)$ & $1(17 \%)$ & $4(67 \%)$ & & 6 \\
\hline & $\mathrm{AD}$ & $15(26 \%)$ & $14(24 \%)$ & $29(50 \%)$ & & 58 \\
\hline \multirow[t]{2}{*}{ MUC6 } & $\mathrm{NE}$ & $0(0 \%)$ & $3(50 \%)$ & $3(50 \%)$ & \multirow{2}{*}{$<0.001^{\mathrm{b}}$} & 6 \\
\hline & $\mathrm{AD}$ & $0(0 \%)$ & $0(0 \%)$ & $58(100 \%)$ & & 58 \\
\hline \multirow[t]{2}{*}{ M-GGMC-1 } & $\mathrm{NE}$ & $6(100 \%)$ & $0(0 \%)$ & $0(0 \%)$ & \multirow{2}{*}{$<0.001^{\mathrm{b}}$} & 6 \\
\hline & $\mathrm{AD}$ & $2(3 \%)$ & $2(3 \%)$ & $54(93 \%)$ & & 58 \\
\hline \multirow[t]{2}{*}{ MUC2 } & $\mathrm{NE}$ & $6(100 \%)$ & $0(0 \%)$ & $0(0 \%)$ & & 6 \\
\hline & $\mathrm{AD}$ & $58(100 \%)$ & $0(0 \%)$ & $0(0 \%)$ & & 58 \\
\hline \multirow[t]{2}{*}{ CD10 } & $\mathrm{NE}$ & $0(0 \%)$ & $0(0 \%)$ & $6(100 \%)$ & \multirow{2}{*}{$0.006^{c}$} & 6 \\
\hline & $\mathrm{AD}$ & $26(45 \%)$ & $12(21 \%)$ & $20(34 \%)$ & & 58 \\
\hline
\end{tabular}

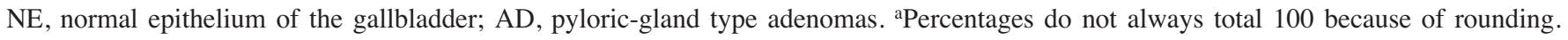
${ }^{\mathrm{b}}$ Stastically compared by Mann-Whitney's U test and Fisher's exact test. ${ }^{\mathrm{c}}$ Evaluated using Fisher's exact test.

MUC2 expression was not observed in $16(28 \%)$ of the 58 adenomas. Out of the 58 pyloric-gland type adenomas, $\geq 30 \%$ of adenoma cells were positive for MUC5AC in $22(38 \%)$ tumors, HGM in 29 (50\%), MUC6 in 58 (100\%), M-GGMC-1 in $54(93 \%)$, MUC2 in none $(0 \%)$, and CD10 in $20(34 \%)$. On the other hand, $<10 \%$ of adenoma cells were positive for MUC5AC in 20 (34\%) tumors, HGM in 15 (26\%), MUC6 in $0(0 \%)$, M-GGMC-1 in $2(3 \%)$, MUC2 in $58(100 \%)$, and CD10 in $26(45 \%)$. Dividing the distribution of positive cells into three groups: $0 \% \leq X<10 \%, 10 \% \leq X<30 \%$, and $X \geq 30 \%$, the relative frequencies of expression for the six immunohistochemical markers were compared between the 58 pyloricgland type adenomas and six normal gallbladder epithelia (Table VI). Although there were only a small number of normal gallbladders used for comparison with pyloric-gland type adenomas, as shown in Table VI, statistically significant differences were present between pyloric-gland type adenomas and non-neoplastic gallbladder epithelium in the expression profile of MUC6 ( $\mathrm{P}<0.001)$, M-GGMC-1 $(\mathrm{P}<0.001)$, and CD10 $(\mathrm{P}=0.006)$ immunostaining.

Expression of p53, KI-67, and CDX2 in 58 pyloric-gland type adenomas of the gallbladder. P53 overexpression was not found in any of the 58 pyloric-gland type adenomas of the gallbladder, including two adenomas with carcinomatous foci. The Ki-67-positive index was $10.3 \pm 5.8 \%$ (mean \pm SD) in the tumors. The distribution patterns of Ki-67-positive cells in the adenomas were sporadic or very focused without aggregation, however, in the two adenomas with carcinomatous foci, where the tumor cells showed a higher degree of atypical cytology, the Ki-67-positive index was 16.2 and $25.1 \%$, and the positive cells had a characteristic focal aggregation pattern.
CDX2 expression was judged as negative in all the 58 pyloricgland type adenomas. Before evaluation, we confirmed that CDX2 was not expressed in the epithelium of 10 normal gallbladders (Fig. 4a). In contrast to those immunohistochemical results, diffuse expression of CDX2 protein was detected in all of our three intestinal-type adenomas of the gallbladder (Fig. 4b and c).

\section{Discussion}

To date, it is well established that MUC2, MUC5AC, and MUC6 are specific immunohistochemical markers for the mucins of intestinal goblet cell, gastric foveolar and pyloricgland type, respectively (11-15,20-23). Mucin phenotype is generally determined by a combination of immunohistochemical tests for the MUC series in various organs. In our institute, both HGM and M-GGMC-1 (or Con A-III) are added to the MUC series when evaluating the mucin expression profile of the gastric phenotype (24-27). In normal human gastric mucosa, HGM (45M1) (28) and $\alpha$-linked Nacetylglucosamine (GlcNAc) residues (M-GGMC-1 or Con A-III) (29) are expressed in the foveolar epithelium and in the deep glands of the antrum and the mucous neck cells of the corpus, respectively. Both are sometimes detected on the luminal surface coat of the epithelium as well as in the cytoplasm, whereas MUC5AC and MUC6 expression is usually restricted to the cytoplasm (24). This is why we consider that immunostaining for HGM and M-GGMC-1 (or Con A-III), in addition to MUC5AC and MUC6, is useful for evaluating the foveolar and pyloric-gland type mucins, respectively.

Very few reports have described the evaluation of the mucin profile of pyloric-gland type adenomas of the gallbladder by 


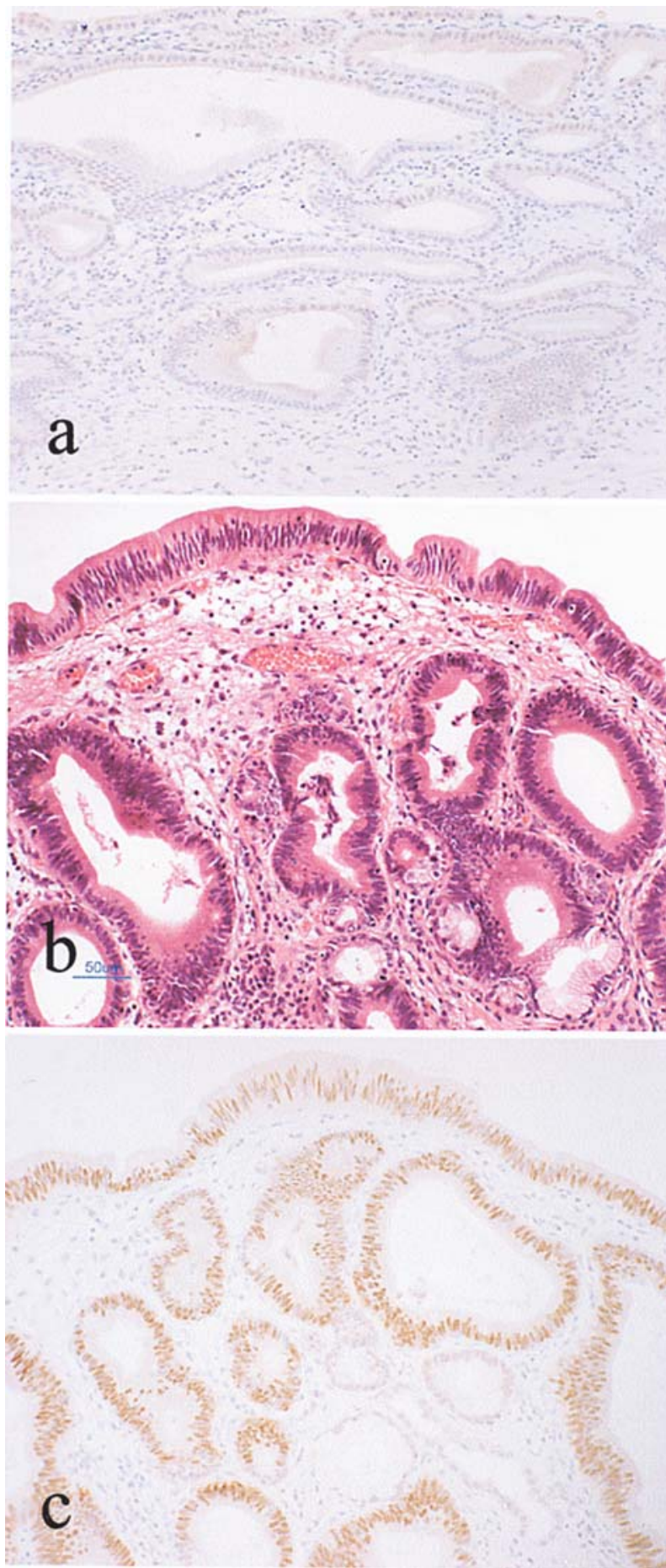

Figure 4. Immunostaining for CDX2. (a) Normal gallbladder epithelium showing no CDX2 expression (x200). (b) H\&E section, and (c) diffuse expression of CDX2 protein by immunohistochemical staining of intestinaltype adenoma of the gallbladder (x200).

using the MUC series $(8,16)$. Chang et al $(8)$ performed immunohistochemical staining on 31 adenomas of the gallbladder, comprising 20 pyloric-gland type, nine intestinal type and two biliary type, using MUC2, MUC5AC and MUC6, as well as cytokeratins CK7 and CK20. In their studies, MUC6 expression without MUC2 or CK20 expression was described as being helpful for establishing their criteria for pyloric-gland type adenoma, in which determination of a positive mucin phenotype was set at $>10 \%$ of positive cells within the total number of tumor cells $(8,16)$. In our study, MUC6 mucin was detected more often than M-GGMC-1, with $\geq 30 \%$ of adenoma cells positive for MUC6 in $100 \%$, and M-GGMC-1 in $93 \%$, of the total 58 pyloric-gland type adenomas, as shown in Table V. On the other hand, when the percentage of positive mucin phenotype was set at $\geq 10 \%$ of positive cells, all the 58 adenomas were classified into the pyloric-gland phenotype, according to the expression profile of MUC6 and M-GGMC-1 that exhibits highly selective reactivity with class III mucins, which are characteristic for gastric pyloric gland cells, as identified by paradoxical concanavalin A (29). Therefore, we suggest that the percentage of positive cells adopted to define pyloric-gland phenotype should be $10 \%$ in pyloric-gland type adenomas of the gallbladder.

The expression profile of CD10 in the biliary epithelium has not yet been well established. CD10, also known as neutral endopeptidase- 24.11 or neprilysin (30), is an endopeptidase responsible for reducing the local concentration of biologic modulators by catabolism (31). Although CD10 was originally identified in acute leukemia as common acute lymphoblastic leukemia antigen (CALLA), it has recently been shown to be expressed not only in a variety of hematopoietic neoplasms, but also in non-hematopoietic neoplasms such as carcinoma of the liver, pancreas, kidney, bladder, prostate and uterus, in addition to sarcoma and malignant melanoma (32-35). Moreover, CD10 is also accepted as the most popular brushborder marker of the small intestine and, especially in gastric carcinoma, it is used as intestinal markers as well as MUC2 in determining whether the carcinoma is of the gastric or intestinal phenotype $(36,37)$. As to the biliary tracts, Loke et al (38) performed immunostaining using anti-CALLA antibody (CD10) on human hepatic tissue, and observed strong immunostaining for the antigen localized only in the area of the bile canaliculi. Furthermore, by immunoelectron microscopy, the chromogen was confirmed to be present along the surface of the biliary microvilli. Scoazec et al (39) immunohistochemically analyzed the expression of polarized plasma membrane proteins of human biliary epithelium, including neutral endopeptidase (CD10), in the various anatomical compartments of the biliary tree. As a result of their study, they described that the apparent expression level of CD10 was high in the large intrahepatic and extrahepatic bile ducts, as well as in the gallbladder. In our study, CD10 expression at the striated border of the epithelium was also frequent in non-neoplastic gallbladder epithelium, while its expression was significantly reduced in pyloric-gland type adenomas of the gallbladder. Therefore, we consider that the loss of the brush-border-like structure of the normal gallbladder epithelium occurs through tumorigenesis towards adenomas of the pyloric-gland phenotype, in which the proper biliary phenotype is diminished. For the first time, we believe that we have demonstrated CD10 expression in pyloric-gland type adenomas of the gallbladder, in comparison with that in normal gallbladder epithelium.

In the present study, we also investigated the expression of CDX2 protein, which is associated with homeobox gene $\mathrm{CDX} 2$, in pyloric-gland type adenomas of the gallbladder. Homeobox genes encode nuclear transcription factors involved in the establishment of differentiation patterns during development, and their maintenance in adults (40). Human 
CDX2, a member of the caudal-related homeobox gene family, plays a crucial role in the regulation of cell proliferation and differentiation in the gut (17-19). While CDX2 is mostly expressed in the villi or differentiated cell compartment of the intestine $(41,42)$, ectopic expression is observed in intestinal metaplasia of other organs (43-46). In the present study, $<10 \%$ of cells were positive for CDX2 in all of the 58 pyloric-gland type adenomas, in contrast to its diffuse expression in the three intestinal adenomas of the gallbladder. In addition, normal gallbladder epithelium, as a negative control for immunohistochemistry, in which CD10 expression was frequently seen, was also negative for CDX2. This supports the hypothesis that CD10 expression in the gallbladder epithelium indicates the phenotype of proper biliary epithelium rather than that of the small intestine, in contrast to the situation in determining the phenotype of gastric carcinoma.

In conclusion, pyloric-gland type adenomas of the gallbladder demonstrated high frequency expression of MUC6 and M-GGMC-1, both of which are specific for pyloric glands, whereas MUC2 expression specific for intestinal goblet cells was rarely seen. Moreover, co-expression of MUC5AC and HGM, both of which are specific for gastric foveolar epithelium, and CD10, which is frequently observed in native gallbladder epithelium, was also observed in a considerable proportion of these tumors. This study reveals a differentiation of pyloric-gland type adenomas of the gallbladder towards pyloric glands in terms of immunohistochemistry as well as morphology, and that they also have the cytological phenotype of gastric foveolar and native gallbladder epithelium. Future research should determine whether this heterogeneity in the mucin expression profile of pyloric-gland type adenomas of the gallbladder is caused by chronological differences in the tumorigenesis or variation in epithelial origin (e.g. metaplastic pyloric type epithelium or proper biliary epithelium) or by the biological nature of this tumor.

\section{References}

1. Albores Saavedra J, Henson DE and Sobin LH: Histological typing of tumours of the gallbladder and extrahepatic bile ducts. In: World Health Organization International Histological Classification of Tumours. Springer-Verlag, Berlin, 1991.

2. Albores-Saavedra J, Henson DE and Klimstra DS: Tumors of the gallbladder, extrahepatic bile ducts and ampulla of Vater. In: Atlas of Tumor Pathology. 3rd edition. Armed Forces Institute of Pathology, Washington, DC, 2000.

3. Albores-Saavedra J, Henson DE and Sobin LH: The WHO Histological Classification of Tumors of the Gallbladder and Extrahepatic Bile Ducts. A commentary on the second edition. Cancer 70: 410-414, 1992

4. Itzkowitz SH, Yuan M, Montgomery CK, et al: Expression of $\mathrm{Tn}$, sialosyl-Tn, and $\mathrm{T}$ antigens in human colon cancer. Cancer Res 49: 197-204, 1989.

5. Lamont JT: Mucus: the front line of intestinal mucosal defense. Ann NY Acad Sci 664: 190-201, 1992.

6. Peat N, Gendler SJ, Lalani N, Duhig T and Taylor-Papadimitriou J: Tissue-specific expression of a human polymorphic epithelial mucin (MUC1) in transgenic mice. Cancer Res 52: 1954-1960, 1992.

7. Yamato T, Sasaki M, Watanabe Y and Nakanuma Y: Expression of MUC1 and MUC2 mucin core proteins and their messenger RNA in gallbladder carcinoma: an immunohistochemical and in situ hybridization study. J Pathol 188: 30-37, 1999.

8. Chang HJ, Kim SW, Lee BL, Hong EK and Kim WH: Phenotypic alterations of mucins and cytokeratins during gallbladder carcinogenesis. Pathol Int 54: 576-584, 2004.
9. Hollingsworth MA and Swanson BJ: Mucins in cancer: protection and control of the cell surface. Nat Rev Cancer 4: 45-60, 2004.

10. Gum JR, Byrd JC, Hicks JW, Toribara NW, Lamport DT and Kim YS: Molecular cloning of human intestinal mucin cDNAs. Sequence analysis and evidence for genetic polymorphism. J Biol Chem 264: 6480-6487, 1989.

11. Ho SB, Niehans GA, Lyftogt C, et al: Heterogeneity of mucin gene expression in normal and neoplastic tissues. Cancer Res 53: 641-651, 1993.

12. Dufosse J, Porchet N, Audie JP, et al: Degenerate 87-base-pair tandem repeats create hydrophilic/hydrophobic alternating domains in human mucin peptides mapped to $11 \mathrm{p} 15$. Biochem $\mathbf{J}$ 293: 329-337, 1993.

13. Toribara NW, Roberton AM, Ho SB, et al: Human gastric mucin. Identification of a unique species by expression cloning. J Biol Chem 268: 5879-5885, 1993.

14. Kim YS and Gum JR Jr: Diversity of mucin genes, structure, function, and expression. Gastroenterology 109: 999-1001, 1995.

15. Ho SB, Roberton AM, Shekels LL, Lyftogt CT, Niehans GA and Toribara NW: Expression cloning of gastric mucin complementary DNA and localization of mucin gene expression. Gastroenterology 109: 735-747, 1995.

16. Chang HJ, Jee CD and Kim WH: Mutation and altered expression of beta-catenin during gallbladder carcinogenesis. Am J Surg Pathol 26: 758-766, 2002.

17. Suh E and Traber PG: An intestine-specific homeobox gene regulates proliferation and differentiation. Mol Cell Biol 16: 619-625, 1996.

18. Chawengsaksophak K, James R, Hammond VE, Kontgen F and Beck F: Homeosis and intestinal tumours in $\mathrm{Cdx} 2$ mutant mice. Nature 386: 84-87, 1997.

19. Lorentz O, Duluc I, Arcangelis AD, Simon-Assmann P, Kedinger M and Freund JN: Key role of the Cdx2 homeobox gene in extracellular matrix-mediated intestinal cell differentiation. J Cell Biol 139: 1553-1565, 1997.

20. Carrato C, Balague C, de Bolos C, et al: Differential apomucin expression in normal and neoplastic human gastrointestinal tissues. Gastroenterology 107: 160-172, 1994.

21. Ho SB, Shekels LL, Toribara NW, et al: Mucin gene expression in normal, preneoplastic, and neoplastic human gastric epithelium. Cancer Res 55: 2681-2690, 1995.

22. Filipe MI, Linehan JM, Durrant LG, et al: Expression of a peptide epitope of the colonic mucin MUC2 in precursor lesions to gastric carcinoma. Eur J Cancer Prev 5: 287-295, 1996.

23. Reis CA, David L, Nielsen PA, et al: Immunohistochemical study of MUC5AC expression in human gastric carcinomas using a novel monoclonal antibody. Int J Cancer 74: 112-121, 1997.

24. Shiroshita H, Watanabe H, Ajioka Y, Watanabe G, Nishikura K and Kitano S: Re-evaluation of mucin phenotypes of gastric minute well-differentiated-type adenocarcinomas using a series of HGM, MUC5AC, MUC6, M-GGMC-1, MUC2 and CD10 stains. Pathol Int 54: 311-321, 2004.

25. Hirono H, Ajioka Y, Watanabe H, et al: Bidirectional gastric differentiation in cellular mucin phenotype (foveolar and pyloric) in serrated adenoma and hyperplastic polyp of the colorectum. Pathol Int 54: 401-407, 2004.

26. Aihara R, Ajioka Y, Watanabe H, Shiroshita H, Akazawa K and Kuwano H: Incidence and distribution of hybrid goblet cells in complete type intestinal metaplasia of the stomach. Pathol Res Pract 201: 11-19, 2005.

27. Ikeda Y, Nishikura K, Watanabe H, Watanabe G, Ajioka Y and Hatakeyama K: Histopathological differences in the development of small intestinal metaplasia between antrum and body of stomach. Pathol Res Pract 201: 487-496, 2005.

28. Smirnova MG, Birchall JP and Pearson JP: TNF-alpha in the regulation of MUC5AC secretion: some aspects of cytokineinduced mucin hypersecretion on the in vitro model. Cytokine 12: $1732-1736,2000$.

29. Ishihara K, Kurihara M, Goso Y, et al: Peripheral alpha-linked $\mathrm{N}$-acetylglucosamine on the carbohydrate moiety of mucin derived from mammalian gastric gland mucous cells: epitope recognized by a newly characterized monoclonal antibody. Biochem J 318: 409-416, 1996.

30. Bene MC and Faure GC: CD10 in acute leukemias. GEIL (Groupe d'Etude Immunologique des Leucemies). Haematologica 82: 205-210, 1997.

31. Shipp MA and Look AT: Hematopoietic differentiation antigens that are membrane-associated enzymes: cutting is the key! Blood 82: 1052-1070, 1993. 
32. Dragovic T, Deddish PA, Tan F, Weber G and Erdos EG: Increased expression of neprilysin (neutral endopeptidase 24.11) in rat and human hepatocellular carcinomas. Lab Invest 70: 107-113, 1994.

33. Dragovic T, Sekosan M, Becker RP and Erdos EG: Detection of neutral endopeptidase 24.11 (neprilysin) in human hepatocellular carcinomas by immunocytochemistry. Anticancer Res 17: 3233-3238, 1997.

34. Chu PG, Arber DA, Weiss LM and Chang KL: Utility of CD10 in distinguishing between endometrial stromal sarcoma and uterine smooth muscle tumors: an immunohistochemical comparison of 34 cases. Mod Pathol 14: 465-471, 2001.

35. Bilalovic N, Sandstad B, Golouh R, Nesland JM, Selak I and Torlakovic EE: CD10 protein expression in tumor and stromal cells of malignant melanoma is associated with tumor progression. Mod Pathol 17: 1251-1258, 2004.

36. Tajima Y, Nakanishi Y, Yoshino T, Kokawa A, Kusano M and Shimoda T: Clinicopathological study of early adenocarcinoma of the gastric cardia: comparison with early adenocarcinoma of the distal stomach and esophagus. Oncology 61: 1-9, 1001.

37. Tsukashita S, Kushima R, Bamba M, Sugihara H and Hattori T: MUC gene expression and histogenesis of adenocarcinoma of the stomach. Int J Cancer 94: 166-170, 2001.

38. Loke SL, Leung CY, Chiu KY, Yau WL, Cheung KN and Ma L: Localisation of CD10 to biliary canaliculi by immunoelectron microscopical examination. J Clin Pathol 43: 654-656, 1990.
39. Scoazec JY, Bringuier AF, Medina JF, et al: The plasma membrane polarity of human biliary epithelial cells: in situ immunohistochemical analysis and functional implications. J Hepatol 26: 543-553, 1997.

40. McGinnis W and Krumlauf R: Homeobox genes and axial patterning. Cell 68: 283-302, 1992.

41. James R, Erler T and Kazenwadel J: Structure of the murine homeobox gene cdx-2. Expression in embryonic and adult intestinal epithelium. J Biol Chem 269: 15229-15237, 1994.

42. Silberg DG, Swain GP, Suh ER and Traber PG: Cdx1 and cdx2 expression during intestinal development. Gastroenterology 119: 961-971, 2000

43. Bai YQ, Yamamoto H, Akiyama Y, et al: Ectopic expression of homeodomain protein CDX2 in intestinal metaplasia and carcinomas of the stomach. Cancer Lett 176: 47-55, 2002.

44. Silberg DG, Sullivan J, Kang E, et al: Cdx2 ectopic expression induces gastric intestinal metaplasia in transgenic mice. Gastroenterology 122: 689-696, 2002.

45. Mutoh H, Hakamata Y, Sato K, et al: Conversion of gastric mucosa to intestinal metaplasia in Cdx2-expressing transgenic mice. Biochem Biophys Res Commun 294: 470-479, 2002.

46. Almeida R, Silva E, Santos-Silva F, et al: Expression of intestinespecific transcription factors, CDX1 and CDX2, in intestinal metaplasia and gastric carcinomas. J Pathol 199: 36-40, 2003. 